\title{
FTC V. FACEBOOK OR BREAKING UP DOMINANT DIGITAL PLATFORMS IN THE TIME OF COVID-19: MOTIVES, RATIONALE, AND POSSIBLE ALTERNATIVES FROM A COMPETITION LAW PERSPECTIVE ${ }^{1}$
}

\author{
Boris Begović, Ph.D., Full professor \\ University of Belgrade School of Law \\ Bulevar Kralja Aleksandra 67, Belgrade, Serbia \\ begovic@ius.bg.ac.rs \\ Nikola Ilić, LL.M., teaching assistant \\ University of Belgrade School of Law \\ Bulevar Kralja Aleksandra 67, Belgrade, Serbia \\ nikola.ilic@ius.bg.ac.rs
}

\begin{abstract}
The Federal Trade Commission of the United States (FTC) filed a Complaint against Facebook on $9^{\text {th }}$ December 2020, in the midst of the COVID-19 crisis. While facing one of the biggest social and economic crises in American history, FTC has enough time and resources to (re) investigate Facebook's acquisitions of Instagram and WhatsApp. This paper analyses motives and rationale behind the FTC's Complaint requesting Facebook's break-up and what could be possible alternatives from a competition law perspective. All the findings suggest that the FTC's Complaint is politically motivated, and the competition authorities should enable digital platforms to expand. However, the expansion should be controlled, to ensure that the benefits for consumers are not undermined by relatively slower (not diversified) technological development.
\end{abstract}

Keywords: Competition Law, Digital Platforms, COVID-19, Facebook, Federal Trade Commission, Mergers and Acquisitions, Relevant Market.

The article originated within the University of Belgrade School of Law research project - Epidemic, Law, Society, 2021. 
"'Forward, the Light Brigade' Was there a man dismayed?

Not though the soldier knew Someone had blundered. Theirs not to make reply, Theirs not to reason why, Theirs but to do and die. Into the valley of Death Rode the six hundred."

The Charge of the Light Brigade by Alfred Tennyson, 1854

\section{INTRODUCTION}

The Federal Trade Commission (FTC) Complaint against Facebook is undoubtedly a hallmark case and a new stage in competition law enforcement pertaining to digital platforms, due to, among other reasons, the introduction of the ex-post merger control. This is relevant not only for the US for several good reasons. First, the US competition law, as competition law with the longest enforcement tradition, is a role model for many jurisdictions around the world. Thus, developments in the US competition law could be relevant for many other jurisdictions. Second, Facebook, as well as other digital platforms, is global, and the outcome of this case could affect not only the users in the US but the users worldwide. Finally, the outcome of this case could have a significant impact on the business conduct of similar digital platforms, also affecting consumer welfare. These insights illustrate the motivation for this paper.

This paper aims to explore the FTC Complaint against Facebook filed during the COVID-19 crisis, to assess its merits and to investigate whether some alternative courses of action could have been available to the FTC. The structure of the paper is consistent with its aim. In the first section, the FTC Complaint is described and analysed, and the motives for such a move are explored. The rationale for the FTC Complaint is then analysed within the framework of an ostensible competition law violation. As the FTC Complaint requests the divestiture or break-up of Facebook, the effects of such a request are investigated, as well as possible alternatives to such divestiture are reviewed and evaluated. The conclusion follows.

\section{The FTC Complaint}

The FTC submitted its Complaint against Facebook under Section 13(b) FTC Act, 15 U.S.C. $\$ 53(\mathrm{~b})$, requesting a permanent injunction and other equitable 
relief against Facebook, to undo and prevent Facebook's anticompetitive conduct and unfair methods of competition in or affecting commerce in violation of Section $5(\mathrm{a})$ of the FTC Act, 15 U.S.C. $\$ 45(\mathrm{a}) .^{2}$

The Complaint consists of seven main parts, excluding three parts concerning jurisdictional issues. ${ }^{3}$ In the first two parts, the Plaintiff explains the nature of the case and the industry background. The third part refers to the definition of the relevant market and monopoly power, while the fourth and fifth part describe anticompetitive conduct and harm to competition in the case at hand. Finally, in the sixth part, the Plaintiff attempts to qualify Facebook's conduct as a violation of the law, and in the seventh, he asks the court to render in his favour and order the breakup.

\subsection{Nature of the case}

In the Plaintiffs words, Facebook is the world's dominant online social network with more than 3 billion users. The Plaintiff states that people regularly use Facebook's services to connect with friends and family and enrich their social lives, but he does not specify the relevant market and services that Facebook provides. ${ }^{4}$ Instead of specifying the services and defining relevant market, the Plaintiff jumps to the conclusion that Facebook maintains its monopoly position by buying up companies that present competitive threats and by imposing restrictive policies to actual and potential rivals that it has not acquired and cannot acquire.

Allegedly, the violation started when Facebook "toppled" its early competitor Myspace and gained monopoly power. Since then, in the Plaintiffs words, Facebook has enjoyed a quiet life through anticompetitive means. However, it is not explained in the Complaint how Facebook toppled Myspace or how, and where, it gained monopoly power (once again, the Plaintiff failed to define the relevant market and Facebook's services). Instead of providing an explanation, the Plaintiff further developed his argument by claiming that subsequently, Facebook identified Instagram and WhatsApp as the two significant competitive threats to its

2 The Complaint was filed with the United States District Court for the District of Columbia, on 9 December 2020, and revised on 21 January 2021. The FTC's Complaint is available at: [https://www. $\mathrm{ftc} . g o v /$ system/files/documents/cases/051_2021.01.21_revised_partially_redacted_Complaint.pdf], Accessed 4 April 2021.

3 Jurisdictional issues in the case at hand are not relevant for this paper, and hence they will be entirely disregarded. The working assumption is that the court has jurisdiction to handle the case.

4 The services that Facebook provides are named in the compliant as "personal social networking services" (\$2), while it is stated that Facebook "monetizes its personal social networking monopoly principally by selling advertising, which exploits a rich set of data about users' activities, interests, and affiliations $[\ldots] ”(\$ 4)$. 
dominant position. As support for this argument, the Plaintiff quoted Facebook CEO's (Mark Zuckerberg's) email from 2008: "it is better to buy than compete". Additionally, the Plaintiff claims that Facebook imposed anticompetitive conditions by restricting access to its digital platform and that Facebook's market position is protected by high barriers to entry and strong network effects.

Competition law specialists would expect more facts and details when describing the nature of the case. In this way, this part of the Complaint seems more like the Plaintiff's wishful thinking than a ground for better understanding of the nature of the case. However, the Plaintiff could have at least mentioned that both acquisitions were previously analysed in detail at approved by the Plaintiff itself. ${ }^{5}$

\subsection{Industry background}

The Plaintiff describes in general how social networks function and what are their advantages in comparison with e-mail and messaging. Social network users can share content (exchange information) and interact with their friends and family in various ways, including posting texts, photos and videos online, commenting, reacting, etc. Nevertheless, it seems that the Plaintiff almost entirely neglected one of the main advantages of social networks in comparison to other means of communication - they are free of charge for the users. In this part of the Complaint, instead of describing the industry and costs and benefits for the users and broader society, ${ }^{6}$ the Plaintiff attempts to present Facebook's business model. In short, as stated in the Complaint, Facebook's business model is mirrored in "selling advertising based on detailed user data". 7 In the Plaintiff's words, Facebook entirely relies on that business model and a substantial portion of its overall revenue comes from selling advertising placements to marketers. ${ }^{8}$

5 See: FTC Press Releases, FTC Closes Its Investigation Into Facebook's Proposed Acquisition of Instagram Photo Sharing Program, 2012, [https://www.ftc.gov/news-events/press-releases/2012/08/ftc-closes-its-investigation-facebooks-proposed-acquisition], Accessed 16March 2021; FTCPress Releases, FTCNotifies Facebook, WhatsAppofPrivacyObligationsinLightofProposedAcquisition, 2014,[https://www.ftc.gov/news/events/press -releases/2014/04/ftc-notifies-facebook-whatsapp-privacy-obligations-light-proposed], Accessed 16 March 2021.

${ }_{6}$ In short, Facebook (as a two-sided platform) connects the two distinct customer groups - users of the network and marketers. In this way, Facebook reduces transaction costs, enables exchanges, and increases consumer welfare. See: Evans, D. et al., Platform Economics: Essays on Multi-Sided Businesses, Competition Policy International, 2011, pp. 2 - 5; Jean-Charles, R.; Jean, T., Two-Sided Markets: An Overview, Institut d'Economie Industrielle, 2004, pp. 13 - 16.

7 Compliant, $\$ 43$.

$8 \quad$ Ibid., $\$ 50$. 


\subsection{Relevant market and monopoly power}

Even though the Plaintiff identified advertising as the major source of Facebook's revenue, in the very next paragraph of the Complaint, he states "personal social networking services in the United States is a relevant market".?

Furthermore, personal social network services are a relevant product market, and these services consist of "online services that enable and are used by people to maintain personal relationships and share experiences with friends, family, and other personal connections in a shared social space". ${ }^{10}$ The Plaintiff defines the United Stated as the relevant geographic market.

There are at least two highly controversial issues concerning the definition of the relevant market. First, if a relevant market, in general, is considered as a grouping of sales for which an unjustified price increase is profitable, ${ }^{11}$ Facebook has no monopoly power over personal network services because these services (as defined by the Plaintiff) are free of charge. Secondly, even if Facebook's services would include advertising, Facebook would not have a significant market power due to many other participants providing the same services, in an entirely different relevant market. ${ }^{12}$

Second, it is a bit strange that the Plaintiff describes Facebook in the Complaint as a global social network, with more than 3 billion users worldwide but specifies only the United States as the relevant geographic market. ${ }^{13}$

Finally, Facebook is a two-sided platform that connects two distinct groups of customers - users (using the network free of charge) and marketers (paying for the advertising services). Both groups create cross-side network effects or indirect network effects, ${ }^{14}$ which should be taken into account when defining the relevant product market. ${ }^{15}$ Qualifying "personal social networking services" as a relevant

\footnotetext{
$9 \quad$ Ibid., $\$ 51$.

$10 \quad$ Ibid., $\$ 52$.

11 Hovenkamp, H., Antitrust and Platform Monopoly, ILE Institute for Law and Economics, Research Paper No. 20 - 43, 2020, p. 10.

12 In addition to specialized websites, television, radio, and other media, an advertiser in the US currently may use many social networking applications such as Twitter, Pinterest, Reddit, Snapchat, Messenger by Google, Tumblr, Discord, GroupMe, TikTok, and many others.

13 Compare, for example, Complaint $\$ 1$ and $\$ 56$.

14 See Rochet, J.; Tirole, J., Platform Competition in Two-Sided Markets, Journal of the European Economic Association, 4/2003, pp. 990 - 1029.

15 Evans et al., 2011, pp. 169-171; Odorović, A., Odredivanje relevantnog tržišta kod dvostranih platformi: problemi i nagoveštaji rešenja, Pravo i privreda, 7-9/2019, pp. 270 - 286.
} 
market just oversimplifies the case and leads to biased conclusions. Obviously, "something is rotten" in this relevant market definition.

\subsection{Anticompetitive conduct}

Following the definition of a relevant market in the Complaint, Plaintiff attempts to describe "Facebook's efforts to deter, suppress, and neutralize personal social networking competition". In essence, all these efforts may be summed in the acquisition of Instagram and WhatsApp and the imposition of new conditions to access the application programming interfaces (API). The two acquisitions are described in detail in the Complaint (excluding the procedure when they were $e x$ ante assessed by the FTC as not harming competition), while the Plaintiff describes the cutting off API access in examples. Facebook deprived potential competitors of its application programming interfaces in several cases, ultimately causing their business failure (Path, Circle, etc.). However, the Plaintiff does not provide any convincing evidence that would support the causal link between cutting off API access and the failures of these (potential) competitors. Moreover, if they were truly innovative and efficient start-ups, they would succeed in any case, as Facebook succeeded at the time when MySpace was the most developed social network. ${ }^{16}$

\subsection{Harm to competition}

In the Plaintiffs opinion, the two acquisitions and the imposition of new conditions on access Facebook's programming interface constitute harm to competition. However, if one would consider that claim in the context of the definition of a relevant market formulated by the Plaintiff ("personal social networking services"), it is unclear how users have been "deprived of the benefits of additional competition for personal social networking." ${ }^{17}$ Due to the positive network effects, it is in the users' greater interest to have one dominant social network than a vast number of smaller networks. Also, as mentioned above, Facebook's services are free for end users. Thus, it is unclear how Facebook could reduce consumer welfare by acquiring new companies and offering more diversified and better services and ultimately a more developed social network. Even if one would alternatively define the relevant market as "advertising services" or "digital advertising services",

\footnotetext{
16 Also, Plaintiff mentioned none of the many successful social networking applications currently in existence in the US (see supra note 10); All these applications and platforms are developing and making a profit regardless of the API.

$17 \quad$ Ibid., $\$ 162$.
} 
it would be equally difficult to qualify Facebook's conduct as significant harm to competition due to the large number of other participants in that market. ${ }^{18}$

\subsection{Violation of law}

In the Plaintiffs opinion, "Facebook's anticompetitive acts violate Section 2 of the Sherman Act, 15 U.S.C. $\$ 2$, and thus constitute unfair methods of competition in violation of Section 5(a) of the FTC Act, 15 U.S.C. $\$ 45(a) " .{ }^{19}$ On one hand, since this part of the Sherman Act refers to the monopolization of trade or commerce ${ }^{20}$ it is not possible for Facebook to provide free services in the relevant market and to violate the law at the same time. On the other hand, if one were to consider (digital) advertising as the relevant market, there would be no monopoly power and attempt to monopolize on Facebook's side and no violation of the law. Similarly, the FTC Act implies trade or commerce, which does not exist between Facebook and its users in the defined relevant market.

\subsection{Prayer for relief}

Based on the allegations in the Complaint, the Plaintiff asked the court for the following reliefs, among others:

i) breaking-up Facebook, including but not limited to Instagram and WhatsApp, ${ }^{21}$

ii) prior notice and prior approval obligation for future mergers and acquisitions, ${ }^{22}$

iii) permanent enjoinment from imposing anticompetitive conditions on APIs and data. ${ }^{23}$

Regardless of the court's final decision in this case, it should be consider what are the true motives behind the breakup request and what could be the effects and possible alternatives to the petition in terms of competition law. These issues could be highly relevant for Facebook and many other digital platforms, and their users, in the US (and Europe). In that sense, the first request will be analysed in detail,

\footnotetext{
18 See supra note 10.

$19 \quad$ Ibid., $\$ 174$.

20 Section 2 of the Sherman Act, 15 U.S.C. $\$ 2$ states: "Every person who shall monopolize, or attempt to monopolize, or combine or conspire with any other person or persons, to monopolize any part of the trade or commerce [emphasis added] among the several States, or with foreign nations, shall be deemed guilty $[\ldots] . "$

${ }^{21} \$ 176$ (B) of the Complaint states: "Divestiture of assets, divestiture or reconstruction of businesses (including, but not limited to, Instagram and/or WhatsApp), and such other relief sufficient to restore the competition [...]."

$22 \quad$ Ibid., $\$ 176(\mathrm{D})$.

$23 \quad$ Ibid., $\$ 176(\mathrm{~F})$.
} 
while the other two will be considered in the light of possible alternatives to breaking up a dominant digital platform. ${ }^{24}$

\section{The motives for the Complaint}

The motives of the FTC to file the Complaint against Facebook, focusing to its breakup, should be considered by analysing the context of such a decision - primarily the origins of the public pressure supporting such a move.

The first origin is the academic community and its recent contributions to the debate about the US competition law and its enforcement. There are two highly visible and influential recent contributions, ${ }^{25}$ whose main points are that the level of competition in the US has plummeted and that the competition law enforcement in the country is too lax. ${ }^{26}$ In both contributions, digital giants, including Facebook, are considered as flagship examples of the main insights related to the decline of competition and the ineffective US competition law.

There is widespread academic concern about the increased industrial concentration in the US economy. This undisputed development has been analysed from various standpoints, both in terms of its origin and consequences and the debate is far from settled. It has been pointed out by prominent IO specialists that industrial concentration is not relevant market concentration, ${ }^{27}$ and is hence irrelevant for measuring competition, and that even (relevant) market concentration is not an indicator of the competition condition in a given market. ${ }^{28}$ Nonetheless, substantial segments of the academic community, both in law and economics, consider that increased industrial concentration, followed with ostensible increase in

24 All the other Plaintiff's prayers for relief, such as declaring that Facebook's course of conduct described in the Complaint violates the Sherman Act, will not be further discussed. The reason for this lies with the defined goal of this paper. Namely, the authors are not interested in the outcome of this particular case but rather in the motives, rationale, and possible alternatives to breaking up a dominant digital platform.

25 Baker, J. B., The Antitrust Paradigm: Restoring a Competitive Economy, Harvard University Press, Cambridge, Mass, 2019; Philippon, T., The Great Reversal: How America Gave Up on Free Markets, Belknap Press of Harvard University Press, Cambridge, Mass, 2019.

26 A review of the Baker's book is provided in: Clifford, W., Back to the good-or were they the bad-old days of antitrust: A review essay of Jonathan B. Baker's The Antitrust Paradigm: Restoring a Competitive Economy, Journal of Economic Literature, 2021, Vol. 59(1), pp. 265 - 284. A review of Philippon's book is provided in: Begović, B., Book review: The Great Reversal: How America Gave Up on Free Markets, Panoeconomicus, Vol. 76(5), 2020, pp. 697 - 706.

27 Shapiro, C., Antitrust in the Time of Populism, Journal of Industrial Organization, Vol. 62(2), 2018, pp. $714-748$.

28 Bryan, K. A.; Hovenkamp, E., Startup Acquisition, Error Costs and Antitrust Policy, University of Chicago Law Review, Vol. 87(2). 2020, p. 336. 
profit margins ${ }^{29}$ and the share of capital in the distribution of national income $\mathrm{e}^{30}$ is a sign of market power and declining competition in the US markets. Accordingly, more vigorous competition law enforcement and even new methods of competition policy are advocated. ${ }^{31}$

The other source of public pressure is the advent of the Neo-Brandeisian movement, a half breed between academic and stakeholders' movement whose main point is that competition law enforcement should accomplish many goals other than competition in the relevant market in terms of preventing price increase and output decline and enabling price decease due to both static and dynamic efficiency. ${ }^{32}$ Hence, the movement advocates a competition law reform that would transform the US antitrust into "antimonopoly", aimed especially at curbing the political power of big business, with technological giants as the prime suspects. According to this view, big companies should be broken up, not predominantly because of the competition harm that they produce effects as such, but rather because of their political power, which enables them to influence decision making processes and to create, among other things, legal barriers to entry to the market. The theoretical underpinning for this move is based on the political theory of firm. ${ }^{33}$ It is rather telling that Lina Kahn, one of the already (though she is 31 years old) well established stars of the Neo-Brandeisian movement, has recently been nominated by US President Biden for FTC commissioner. ${ }^{34}$ It seems that the antitrust populism has penetrated the core of the US antitrust legislation enforcement and it seems that the COVID-19 pandemic, which made digital communication between people much more important in daily life than it had been previously, has increased the pressure for the FTC to "do something".

29 Basu, S., Are Price-Cost Markups Rising in the United States: A Discussion of the Evidence, Journal of Economic Perspectives, Vol. 33(3), 2019, pp. 3 - 22. The increase of profit margins with increasing share of fixed costs does not necessary imply an increase in profit rates. De Locker, J., Eeckhour, G. U., The Rise of Market Power and Macroeconomic Implications, Quarterly Journal of Economics, Vol. 135(2), 2020, pp. $561-644$.

30 Autor, D. et al., Concentration and the Fall of the Labor Share, American Economic Review, Vol. 107(5), 2017, pp. $180-185$.

31 Even a Pigouvian tax on the size of the firm has been proposed. See: Nobel Laureate Paul Romer on How to Curb Big Tech's Power, 2021, [https://www.chicagobooth.edu/why-booth/stories/stiglercenter-antitrust-conference-paul-romer], Accessed 4 April 2021.

32 Khan, L., The Amazon Antitrust Paradox, Yale Law Journal, Vol. 126(3), 2017, pp. 710 - 805.

33 Zingales, L., Towards a Political Theory of the Firm, Journal of Economic Perspectives, Vol. 31(3), 2017, pp. $113-130$.

34 See: White House Statements and Releases, President Biden Announces his Intent to Nominate Lina Khan for Commissioner of the Federal Trade Commission, 2021, [https://www.whitehouse.gov/briefing-room/statements-releases/2021/03/22/president-biden-announces-his-intent-to-nominate-lina-khan-for-commissioner-of-the-federal-trade-commission/], Accessed 4 April 2021. 
Hence, taking all this public pressure into account, and especially allegations about Facebook's political involvement or at least the political consequences of its operations, it is not surprising that the FTC, which does not operate in a political vacuum, has stepped forward with the Complaint. Whether the Complaint has competition law merit does not depend on the FTC's motives, but understanding the broader context may explain the possible lack of merit of the Complaint if that is the finding of the analysis.

\section{THE RATIONALE FOR THE COMPLAINT}

It is a challenging task to find a rationale for any competition law Complaint in a case when (free) personal social networking services constitute the relevant product market. With that as the starting point, new acquisitions and enlargement of the social network could hardly harm consumers. Quite the opposite, due to economy of scale and scope, improvement of services, and increased network effects, consumer welfare would increase through such acquisitions. Furthermore, even if the relevant product market includes (digital) advertising services, almost the same conclusions are valid due for a considerable number of other service providers in that market. That is demonstrated by analysing and closer exploring the Instagram and WhatsApp acquisitions.

\subsection{Acquisition of Instagram}

As described in the Complaint, during the first decade of the $21^{\text {st }}$ century, social network customers significantly changed their behaviour. They started to shift from computers to smartphones and other mobile devices. ${ }^{35}$ It is true that Instagram, as a more suitable social networking app for mobile devices, used that change in customer behaviour to gain more users and increase its popularity, which threatened Facebook's apps for taking, sharing, and commenting photographs. Facebook wanted to keep its users and, if possible, to offer the same or similar services as Instagram. However, that does not mean Facebook's conduct can be automatically qualified as significant harm to competition and violation of the law. ${ }^{36}$ To conclude whether the acquisition is significant harm to competition a counterfactual analysis is needed - something that the Plaintiff missed to do. It

\footnotetext{
35 Complaint, $₫ 78$.
}

36 In that sense, it is unclear what is the Plaintiff is trying to prove when quoting Facebook's internal correspondence in the Complaint, identifying Instagram as a superior social networking application at the time, and revealing Facebook's intention to improve its services and take over Instagram (Complaint, $\$ 82$ - \$104). This is neither mala fidei nor illegal conduct per se. On the contrary, a desire to improve its services and be more efficient is the main driving force in market economy. 
should be analysed and explained what the consequences would be if the acquisition did not take place and compare these with the existing consequences.

Had Facebook not acquired Instagram, consumers would have continued to use (at least) two different social networking apps instead of one. In other words, if a consumer had wanted to share their photos online, they would have had to share them via both apps to ensure that all of their friends and family could see the post. Moreover, one would have had to use two different sets of tools to modify and prepare photos for sharing (the greater the difference between these tools, the greater the difference would be between the two versions of photos, and it would become harder to send the same photo, i.e. the same message, to all friends and family). Besides difficulties in communication between customers using different tools and apps, the customer's opportunity costs of time would have been much higher. Namely, customers would have spent more time allocated to sending and sharing photos online, and on the top of that the quality of communication would be lower. Therefore, the acquisition significantly reduced costs and increased consumer welfare.

Furthermore, the counterfactual analysis should include advertising, even though the Plaintiff excluded advertising services from the relevant product market. ${ }^{37}$ In this sense, had Facebook not acquired Instagram, marketers would have had one additional social networking app as a potential advertising service provider. However, that does not mean the marketers would have been in a relatively better position. Namely, without the Instagram acquisition, it would have been even more demanding and more costly for marketers to reach their target groups. When some of their (potential) customers are using one network and some the other, and these networks are not compatible, marketers would have to pay for both networks' services. On one hand, the individual price for each of the two networks probably would have not be lower because neither of the two providers could achieve economy of scale. On the other hand, the quality of services would be lower due to the lower functionality and visibility of individual networks. ${ }^{38}$ Accordingly, the increased number of advertising services providers does not necessary imply that consumer welfare would increase.

Finally, instead of conducting a counterfactual analysis, the Plaintiff claims in the Complaint that "Facebook cannot substantiate merger-specific efficiencies or

37 The Complaint, $\$ 51$ and $\$ 52$; As stated before, Facebook is a two-sided platform, and both sides are and should be equally relevant when analysing the effects of acquisitions on consumer welfare.

38 Due to the acquisition, Facebook was able to make the two networks compatible, achieve economies of scope, improve the quality and functionality of both applications functioning within the same network. 
other procompetitive benefits sufficient to justify the Instagram acquisition". ${ }^{39}$ Nevertheless, the burden of proof lies with the Plaintiff, which should prove that the (already approved) acquisition constitutes significant harm to competition, not with the Defendant.

\subsection{Acquisition of WhatsApp}

As a result of the change in consumer behaviour, besides the increase in popularity of the apps for sending and sharing photos, mobile messaging has also been transformed dramatically. Instead of traditional text messaging via short message service (SMS) or multimedia message service (MMS) protocols, consumers abruptly switched to text messaging via internet-based, over-the-top mobile messaging apps (OTT messaging). ${ }^{40}$ In that sense, Facebook has been trying to improve its messaging app (Messenger) and follow the new trends in social networking. However, in that aspect of networking, i.e. mobile messaging, WhatsApp was one of the most successful apps, gaining several thousand new users per day and striving to connect 400,000 people worldwide in 2014. Facebook wanted to keep its users and to offer the same or similar messaging services. Once again, Facebook's sole intention to improve its services and possibly acquire WhatsApp is not per se a violation of the law nor has resulted in significant harm to competition..$^{41}$ The only relevant issue is what the economic consequences would be if the acquisition did not take place, i.e. what would be the result of the counterfactual analysis?

Had Facebook not acquired WhatsApp, consumers would have continued to use (at least) two different mobile messaging apps instead of one. In other words, if a user would have wanted to send a message to their friends or family, they would have had to check which app they are using and then communicate using the same app. Moreover, since the two apps (Messenger and WhatsApp) were not compatible prior to the acquisition, one had to have and use two different sets of contacts. In addition to these difficulties in establishing and maintaining communication, users would have to constantly switch from one app to the other, which could further increase opportunity costs of time and reduce consumer welfare. Namely, users would spend more time on messaging, and the quality of messaging services

39 The Compliant, $\$ 106$.

40 Over-the-top (OTT) messaging services implies services directly provided to consumers via the Internet. OTT bypasses telecommunication companies that traditionally provide such services. Due to the lower fixed and variable costs, OTT messaging services providers are much more efficient than traditional providers.

41 This should be taken into account when reading the Complaint ( $\$ 115-\$ 127)$. Namely, the Plaintiff quotes Facebook's internal correspondence revealing Facebook's intention to acquire WhatsApp without ever analysing what could be the economic consequences of the acquisition. 
would be lower because neither of the two networks would achieve economy of scale and substantially improve their functionality. Therefore, WhatsApp acquisition reduced costs and increased consumer welfare.

On the other side of the digital platform, marketers too could benefit from the acquisition. Before 2014, WhatsApp had only 300,000 users worldwide, ${ }^{42}$ while, after the acquisition, due to the increased network effects and economy of scope, it gained the trust of more than a billion users. In that sense, marketers may reach their target groups within one network, and the advertising price would not change significantly (if at all) due to the large number of advertisement service providers in the market. ${ }^{43}$

Accordingly, the conclusion on the counterfactual analysis is that the acquisition is beneficial for all relevant stakeholders: the acquisition is beneficial for Facebook because it enables it to gain more users worldwide and materialise economies of scope, while, at the same time, it is beneficial for the customers (users and marketers) due to the increase in efficiency, network functionality, and network effects. In other words, if one observes from the relevant market participants' point of view, it seems there is no rationale for any complaint related to the acquisition. ${ }^{44}$ However, this does not mean this type of acquisition (a dominant platform acquiring start-ups) should not be notified at all. Possible alternatives to breaking up dominant digital platforms, from a perspective of competition law, will be analysed separately.

\section{THE EFFECTS OF BREAKING UP FACEBOOK}

There is a long and troublesome history of break-ups in the history of the US competition law, starting with the controversial Standard Oil case in 1911. It was demonstrated that most of the break-ups were failures. ${ }^{45}$ Perhaps the only one that

42 Statista, [https://www.statista.com/statistics/260819/number-of-monthly-active-whatsapp-users/], Accessed 26 March 2021.

43 One of the Plaintiff's argument is that the two acquisitions eliminate potential competition that could threaten Facebook's market position in the future. However, the Plaintiff mentioned none of many other relatively large companies and start-ups currently participating in the US (digital) advertising market.

44 Possible complaints related to private data protection are not closely related to competition law and thus are not discussed in this paper. Nonetheless, it is reasonable that the general rule should apply the acquirer is bound by all of the acquired's firm contractual obligations related to data protection.

45 Kovacic, W. E., Failed Expectations: The Troubled Past and Uncertain Future of the Sherman Act as a Tool for Deconcentration, Iowa Law Review, Vol. 74(4), 1989, pp. 1105 - 1150; Crandall, R. W., The Failure of Structural Remedies in Sherman Act Monopolization Cases, AEI-Brookings Joint Center for Regulatory Attitudes, Working Paper 01.05., 2001; Sullivan, E. T., The Jurisprudence of Antitrust Divestiture: The Path Less Travelled, University of Minnesota Law School, Vol. 86(2), 2002, pp. 565 - 613. 
produced a desirable outcome, the only success story, is the consensual break-up of AT\&T and the creation of the Baby Bells, followed by vertical separation and introduction of competition into long-distance telephony.

It is intuitive that the probability of an unsuccessful break up is substantial. It is difficult even impossible to unscramble the eggs, as the assets of the company are fully integrated and used for the operation of a single entity. Nonetheless, the specific difficulties in the case of the proposed Facebook break-up should be identified. The best way to start it would be to consider the business motives/aims of Facebook in both mergers, i.e. acquisitions of both Instagram and WhatsApp. There is no doubt that one of the motives was elimination of potential competitors, i.e. they were killer acquisitions. ${ }^{46}$ In that way, it is very convincing that the acquisitions have harmed the competition - a reasonable theory of harm. Nonetheless, Facebook profited from these mergers in other ways.

The first one is economy of scope, which enabled it to diversify its supply portfolio and to allocate overhead costs to more output units, decreasing average costs, i.e. increasing production efficiency. It is economy of scope, not scale that was achieved, as these mergers were conglomerate mergers, because the acquired companies (especially WhatsApp) operated in different relevant markets. Breaking up Facebook along the merger lines would not only undermine economy of scope but would fail to re-establish competition in the relevant market, as the new/old undertakings would operate in their separate relevant markets. WhatsApp would, for example, compete with other messenger services, as it does today as a Facebook brand.

The other reason for the increase in Facebook's efficiency is the gathering of various assets of the acquired companies. Some of them are IP related: patents and trademarks. For example, it is much cheaper to acquire the WhatsApp trademark than to invest in a new brand in the messaging services market. So, it was a reasonable, cost-reducing business decision to diversify the supply portfolio by acquiring WhatsApp compared to investing in Facebook's own new entry operator. Breaking-up Facebook along the merger lines would not prevent the company from entering the messenger services market, only this time with a substantially higher costs - evident inefficiency.

46 For example, Kevin, A. B.; Erik, H., Startup Acquisitions, Error Costs, and Antitrust Policy, The University of Chicago Law Review, Vol. 87, p. 345, defines killer acquisitions as follows: "In these acquisitions, the acquirer does not utilize or further develop the target's innovation, but instead merely prevents such innovation from entering into competition with the incumbent's own product". 
It is not only IP related assets that are gathered is acquisitions: there is also specific software industry know-how that cannot be protected as IP. Different production teams in different companies, developing specific software, create distinctive know-how that can be obtained only by acquiring the firm. Although specific human capital is not an asset (strictly speaking in accounting terminology), it is also acquired through such mergers. It is feasible to acquire that capital on the labour market, negotiating individual contracts with all the people. The transaction costs of such a way of obtaining human capital are extremely high, so acquisition of a firm for such a reason is perfectly reasonable,${ }^{47}$ not only for the acquiring firm, but also for the consumer welfare perspective, because the transaction costs are minimised. ${ }^{48}$ Since there is a constant and substantial flow of human capital within a firm, the eggs have been scrambled, it is highly uncertain how the break-up would be done, i.e. along which lines the labour force (human capital) would be divided. It could be expected, though, that further adjustments, i.e. transfer of labour, would occur in the market, with related transaction costs. Furthermore, the human capital of a firm is not only the sum of the human capital of its employees, since there is a substantial premium to it embodied in the "team spirit" that further increases production efficiency, especial in research and development activities, boosting innovations. The break-up would inevitably completely destroy the team spirit, or at least substantially undermine it.

Finally, breaking-up Facebook, "including but not limited to Instagram and WhatsApp" would effectively introduce expost merger control in the US competition law. Like almost every other jurisdiction in the world, there is ex ante merger control in the US, introduced by the Hart-Scot-Rodino Act of 1976. Accordingly, either the FTC or the DoJ must be notified of every merger that complies with the merger notification rule, i.e. above the threshold set by these rules, and these authorities decide whether they will challenged the merger before the courts. If the merger is not challenged, then it is cleared. ${ }^{49}$ Facebook notified the FTC of the mergers/acquisitions. The FTC formally cleared the merger with Instagram in 2012, and informed, although between the lines, that it would not challenge the merger with WhatsApp in the court. That means that in the legally stipulated process of ex ante merger control Facebook received feedback from the authority

47 Polsky, G. D.; John F. C., Acqui-hiring, Duke Law Journal, Vol. 63(2), 2013, pp. 281 - 346.

48 That is not to say that there are no transaction costs of the capital transaction, i.e. of the merger itself. Nonetheless, these transaction costs are fixed costs for all the transfers of assets and human capital, so substantial economy of scale exists.

49 Basically, the US pattern of merger control is very similar to the European one, only the courts are not involved in the first instance of deliberation, though the right of appeal does exist. On the EU level, the EC is notified of the merger decision, and it is the EC that decides whether to clear the merger, to clear it conditionally, or to prohibit it. 
in change that these mergers have been cleared and that they do not, on balance, harm competition.

A few years later the very same competition law authority (the FTC) claims that those mergers harmed competition and asked the courts to effectively annul them. This does not fall short of the ex post merger control, introduced after ex ante merger control has already been exercised. This precedent creates substantial legal uncertainty for undertakings that are considering mergers. Such uncertainty will be biased, as it will deter from the merger those merging parties whose mergers would be beneficial for economic efficiency and which would increase consumer welfare. This is perhaps the most devastating effect of such a move by the FTC - if it is supported by a court decision.

\section{POSSIBLE ALTERNATIVES}

As demonstrated, the acquisition of start-ups by a dominant digital platform could be beneficial for relevant stakeholders due to the increase in efficiency, network functionality, and network effects. However, there is widespread concern that these types of acquisitions may (pre)determine the future direction and pace of technological development. Namely, it would not harm competition if one were to invent a superior digital platform on their own but could be disputable, from a competition law perspective, if one were to create a superior digital platform through contracts. In this sense, a clear distinction should be made between these two cases..$^{50}$ Furthermore, concerning creating a superior network through contracts, the two sub-cases may be distinguished: a dominant platform planning and executing acquisitions of technologically advanced (start-up) companies, and a dominant platform's behaviour constituting significant harm to competition. The first sub-case does not necessarily imply the second sub-case. Nevertheless, there are reasonable indications that competition authorities should closely monitor and regulate the first sub-case in any event.

One of the main concerns related to establishing or enlarging a dominant platform through contracts is that future technological development will have a strictly predetermined path. Namely, when a digital platform is large enough and enjoys significant market power, new start-ups do not have strong incentives to invent or develop alternative technological solutions. The most profitable strategy for relatively small start-up companies would be to focus on $\mathrm{R} \& \mathrm{D}$ activities that

50 For the similar distinction see Bryan A. K.; Hovenkamp, E., Antitrust Limits on Startup Acquisition, Review of Industrial Organization, Vol. 56(4), 2020, pp. 632-633; Of course, when there is significant harm to competition, the acquisition should not be approved. 
could improve the existing technology, so it can licence the improved technological solutions to a dominant network or be acquired. In that way, the technological development pace would be slower and consumer welfare would be lower even though a dominant platform did not harm competition in the market. ${ }^{51}$ To put it simply, economies of scale and powerful network effects are like a magnetic force, not only for users of a dominant digital platform but also for all competitors in the market, attracting them to invest in the same technology. The crucial question is whether the competition authorities (in the US and Europe) should ban these technology transfers through contracts and acquisitions or not?

It seems that the dissolution or break-up of a dominant platform is not an appropriate solution for the described problem for at least two reasons. First, as already mentioned, this would imply ex post annulment of the already approved acquisitions and generate significant legal uncertainty. Second, breaking up the company does not solve the problem of the magnetic force of the dominant platform and the relatively slow pace of technological development. On the contrary, by breaking up a dominant platform, competition law authorities could further slowdown the technological development. Namely, technology has already been developing in one direction, and authorities would effectively ban its fusion by breaking up a dominant platform, depriving all customers of the benefits derived from economies of scope and network effects. Furthermore, one platform will eventually become dominant again, based on its technology with substantial economy of scale, and competition authorities will once again constrain the platform in order to attract smaller companies to contribute to further technological development and materialisation of economies of scope and network effects. In that sense, breaking up a dominant platform when there is no significant harm to competition (the acquisitions were approved) only slows down technological development and reduces consumer welfare.

The alternative solution could imply enabling technology fusion and increasing competition in the market at the same time. The authorities could implement this solution in practice instead of the break-up, and the key to its implementation is non-exclusive licensing. Namely, on one hand, when approving the formation or enlargement of a dominant platform based on contracts (sub-case when there is no significant harm to competition), competition authorities may impose the non-exclusive licencing condition on the technology transfer. On the other hand,

51 Radulović B., Reassessing the Costs of Patents, in: Vasić R.; Ivana K. (eds.), Razvoj pravnog sistema Srbije i harmonizacija sa pravom EU, University of Belgrade Faculty of Law, 2006, pp. 171-172. "The desire of acquiring the monopoly power that patents confer encourages too many innovators to pursue the same research projects entering a 'race to patent' which needlessly absorbs a portion of the available resources." 
when approving a merger that will establish or enlarge the formation or enlargement of a dominant platform based on acquisitions, competition authorities may impose the patent pledge or non-exclusive licencing condition. ${ }^{52}$ In that way, a dominant platform could acquire new technologies and companies, while all other companies could use the same technology and develop it further in different directions. In that sense, competition authorities would not deprive consumers of the benefits derived from the materialisation of economies of both scale and scope and network effects, or of endless possibilities related to further (diversified) technological development.

Applied to the Facebook case, it seems that the dissolution or break-up would not resolve the issue. On the contrary, as previously explained, it could slow down further technological development and deprive consumers of benefits deriving from the economies of scope and network effects. Furthermore, this approach would not solve the problem of the directional technological development, i.e. the magnetic attraction of the dominant platform's technology. Instead of breaking up Facebook, the authorities could condition all technology transfers (pro futuro) to be conducted under non-exclusive or open licencing terms. In that way, Facebook could achieve economies of scope and increase network effects, while potential competitors could develop alternative and possibly more efficient technological solutions.

Furthermore, the competition concern regarding Facebook as the dominant platform can be overcome by introducing compulsory interoperability with pooling of all digital platforms/networks as a competition remedy. ${ }^{53}$ Interoperability occurs when the technology systems of multiple firms are compatible, so that users can process instructions for all of them. Polling includes sharing of information, especially on the customer base. In the competitive markets, two-sided platforms have strong incentives to share information because in that way both direct and indirect network effects are achieved, new customers can be attracted, and economy of scale can be achieved. In the case of Facebook and other social networking sites technical data pooling would produce a much larger group of customers - users and marketers. All the participant firms would have the advantage that accrue

52 A patent pledge is a pledge of a patent owner that all its (potential) competitors can use and further develop the same technology free of charge. See, for example: Contreras L. J., The Evolving Patent Pledge Landscape, Centre for International Governance Innovation, CIGI Papers No. 166, 2018.

53 Kades, M.; Morton F. C., Interoperability as a Competition Remedy for DigitalNetworks, Washington Center forEquitableGrowth, WorkingPaper,2020; Hovenkamp,H., op.cit.,p.6; StiglerCentrefor theStudy ofthe Economy and the State, Stigler Committee on Digital Platforms - Final Report, 2019, [https://www.publick nowledge.org/wp-content/uploads/2019/09/Stigler-Committee-on-Digital-Platforms-Final-Report. pdf], Accessed, 09 April 2019. 
from a larger joint database and they would have to compete with the quality of their individual services, not on the size of the database. It is users that will ultimately select with social network platform they will use, and they could switch from one to the other without losing any it their contacts. Technical data pooling in the service of interoperability (list of users and their contact details) should be distinguished from the private data pooling (e.g. behaviour of users, their search history). ${ }^{54}$

This is basically what is known as interconnection in the telephony. Customers of one operator can dial all customers using all other operators and can be dialled by all customers of all operators, hence the network effects are maximised. Although there are many telephone companies, it still remains a unitary network. It enjoys all of the network externalities that result from having a single, very large network. ${ }^{55}$ With compulsory interoperability and technical data pooling, there would be a single social network platform - a unitary network - with many firms, including Facebook, operating that network and competing with each other in the quality of the service they provide.

The EU has a somewhat similar approach, as it recognises the immense economic and social effects of digital platforms and is currently working on further improvement of its legislative framework. ${ }^{56}$ Among other formal proposals, in December 2020, the European Commission unveiled the Digital Services Act, which introduces a series of new, harmonised EU-wide obligations for digital service providers. ${ }^{57}$ Moreover, the Commission proposed the Digital Markets Act, which should ensure fair and open digital markets by regulating dominant digital platforms or the gatekeepers. ${ }^{58}$ As stated in this proposal, the gatekeepers should be regulated ex ante, i.e. they should abide by a set of obligations enabling the better functioning of digital platforms, interoperability, data protection and transparency. Even though this is still a draft regulation, it seems that Europe is exploring new solutions that would enable digital platforms to achieve economies of scale and scope and increase network effects, while their technology and technical users' data would become more accessible to competitors and thus, the pace of further

\footnotetext{
54 Supra note 44.

55 Hovenkamp, H., op. cit., p. 100.

56 European Parliament, Online Platforms: Economic and Societal Effects, EPRS study, March 2021.

57 See: European Parliament, Digital Services Act: EU Legislation in Progress, EPRS study, March 2021.

58 Caffarra C.; Morton F. C., The European Commission Digital Markets Act: A translation, Vox EU, 5 January 2021, [https:/voxeu.org/article/european-commission-digital-markets-act-translation], Accessed 2 April 2021; European Commission, The Digital Markets Act: Ensuring Fair and Open Digital Markets, 2021, [https://ec.europa.eu/info/strategy/priorities-2019-2024/europe-fit-digital-age/digital-markets-act-ensuring-fair-and-open-digital-markets_en], Accessed 02 April 2021.
} 
technological development could still be blistering. At the same time, on the other side of the pond, it seems that there is no understanding nor tolerance for dominant digital platforms, except when it comes to their political (ab)use. Ironically, even though Europe has developed its competition law predominantly under the influence of the US law, when it comes to digital platforms, the US is now the one who should look up to other legal systems in search of better ideas and new legal solutions.

Apart from the alternatives to the break-up, based on the non-exclusive (or open) licensing, interoperability, data pooling and other similar behavioural remedies, the question is whether there are some other non-behavioural alternatives to the break-up of Facebook and other digital giants.

The obvious one, which would not affect their economy of scale and scope, would be economic regulation of Facebook. The rationale for that regulation must be the natural monopoly argument. If the industry is a natural monopoly, then due to subadditivity of the costs function, competition is neither sustainable nor desirable. It is not sustainable because of the decreasing average costs each competitor tries to crowd out competition in order to get a bigger share of the market, as the increased output would make that competitor more competitive. The dynamic equilibrium of entries and exits is a corner solution: only one firm on the supply side. Competition is not desirable, because the exogenous average costs of one firm, due to subadditivity, are inevitably lower than the average costs of two or more firms. ${ }^{59}$

The question is whether Facebook is a natural monopoly. As to being "natural", there are no reliable information on the firm's cost function, save only that the firm is a multi-product one; there is no information whether there is subadditivity of the cost function or not. ${ }^{60}$ Furthermore, the cost function depends on technology and in the IT industry technology is changing daily, so even if there is subadditivity at one moment, that information is not relevant even for the near future. That was exactly the case in the telecommunication industry when natural monopoly was abolished because of the introduction of new technology, which changed the cost function. The technological progress in the IT industry is much more intensive.

59 Endogenous average costs could be higher due to X-inefficiency, i.e. the production inefficiency of a monopolist.

60 Baumol J. W.; Panzar, C. J.; Willig D. R., Contestable Markets and the Theory of Industry Structure, Harcourt Brace Jovanovich Publishers, San Diego, 1982; Hovenkamp. H., op. cit., 17-28. 
Not only is Facebook not a "natural" monopoly, but it is also not a monopoly at all. There are many substitutes even in the relevant market of "personal social networking services", as specified by the FTC. The point is that social networking services are a highly differentiated product. Some of them are general, some of them are more or less specialised. So, this market is definitely a monopolistic competition market, i.e. a market with competition of imperfect substitutes. Furthermore, as already pointed out in this paper. Facebook is a two-sided platform, i.e. a two-sided market, and even if there is a monopoly on one side, that does not necessary mean that the firm is a monopolist.

For the sake of the argument, let us suppose that Facebook is a natural monopoly and that there is a rationale for economic regulation. The long history of economic regulation of natural monopolies, especially in the US, has demonstrated that it hardly provides efficient outcomes. There are two main reasons for this. The first one is asymmetric information - a situation where regulated companies are much better informed about relevant issues (the costs function, level of effort to minimize the costs etc.) than the regulator. The other one is that regulators are biased towards the regulated firms, as it has been demonstrated by the economic theory of regulation. ${ }^{61}$

The other pro futuro alternative is reformed and more stringent merger control, which would prevent killer acquisitions and therefore protect (potential) competition. One solution for that would be to lower the notification threshold, i.e., to include those still small potential competitors in the merger screening process, as their acquisitions would then be notified. ${ }^{62}$ The problem with this solution is that the notification threshold then must be rather low and that would substantially increase the administrative burden to both the competition authorities and undertakings. Many mergers that are harmless for competition would then be notified and reviewed. Furthermore, in the case of both Instagram and WhatsApp acquisitions, both were notified and then cleared by the FTC. So, in this specific case, it is not the low notification threshold that matters.

The other idea is to use the acquisition price as the indicator of the threshold for the merger notification, rather than turnover. ${ }^{63}$ It is true that this price releases true economic value of the capital transaction and provides the hint of acquired forms, i.e. economic value of preventing (future) competition. Although economically sound, there are at least two practical problems. One is that this criterion cannot

\footnotetext{
${ }_{61}$ Stigler, J., The Theory of Economic Regulation, Bell Journal of Economics and Management, Vol. 2(1), 1971 , pp. $3-21$.

62 Philippon, T., op. cit., p. 274.

63 Ibid., 275.
} 
be used in the case of proper mergers (fusions), so dual notification systems would have to exist. The other one is that the acquisition price can be quite manipulated legally. In some cases, it would not be public information at all. Nonetheless, this could be promising line of thinking with some suggestions already made on how to overcome practical obstacles. ${ }^{64}$

Introduction of ex post merger control is hardly an alternative solution, as this is effectively the bottom line of the FTC Complaint. The only difference is that in this very case the FTC already cleared both acquisitions.

\section{CONCLUSION}

It is evident that there has been a substantial political pressure on the FTC to file the Complaint against Facebook, pressures based not only on the competition law viewpoint. "Do something (in the midst of the COVID-19 crisis)" was the main message, and the FTC decided to do something big - that is why there is a petition to the court to break up Facebook. A sad echo of the Standard Oil case from more than a century ago.

It has been demonstrated in the paper that the case has not been prepared well and that the argumentation for the break-up is rather poor. Furthermore, alternatives to the break-up - more promising from the consumer welfare perspective - have been identified.

These alternatives should be further explored, and among them the priority should be the details needed for the enforcement non-exclusive licensing, compulsory interoperability and technical data pooling, as well as the details for the reform of the ex ante merger control procedure that would minimise the probability of killer acquisitions of potential competitors.

It was not the aim of the paper to analyse the probabilities regarding the outcome of the case, i.e. to explore what the ruling of the court might be. It remains to been seen whether the US courts will be a match for the FTC Complaint in the way the Russian artillery was to the Charge of the (British) Light Brigade.

64 Bryan, K. A.; Hovenkamp, E., Startup Acquisition, Error Costs and Antitrust Policy, University of Chicago Law Review, Vol. 87(2). 2020, pp. 331 - 356; Bryan, K. A.; Hovenkamp, E., Antitrust Limits on Startup Acquisition, Review of Industrial Organization, Vol. 56(4), pp. 615-636. 


\section{REFERENCES}

\section{BOOKS AND ARTICLES}

1. Autor, D. et al., Concentration and the Fall of the Labour Share, American Economic Review, Vol. 107(5), 2017, pp. $180-185$

2. Baker, J. B., The Antitrust Paradigm: Restoring a Competitive Economy, Harvard University Press, Cambridge, Mass, 2019

3. Basu, S., Are Price-Cost Markups Rising in the United States: A Discussion of the Evidence, Journal of Economic Perspectives, Vol. 33(3), 2019, pp. 3 - 22

4. Baumol J. W.; Panzar, C. J.; Willig D. R., Contestable Markets and the Theory of Industry Structure, Harcourt Brace Jovanovich Publishers, San Diego, 1982

5. Begović, B., Book review: The Great Reversal: How America Gave Up on Free Markets, Panoeconomicus, Vol. 76(5), 2020, pp. 697 - 706

6. Bryan A. K.; Hovenkamp, E., Antitrust Limits on Startup Acquisition, Review of Industrial Organization, Vol. 56(4), 2020, pp. 615 - 636

7. Bryan, A. K.; Hovenkamp, E., Startup Acquisition, Error Costs and Antitrust Policy, University of Chicago Law Review, Vol. 87(2), 2020, pp. 331 - 356

8. Clifford, W., Back to the good-or were they the bad-old days of antitrust: A review essay of Jonathan B. Baker's The Antitrust Paradigm: Restoring a Competitive Economy, Journal of Economic Literature, 2021, Vol. 59(1), pp. 265 - 284

9. Contreras L. J., The Evolving Patent Pledge Landscape, Centre for International Governance Innovation, CIGI Papers No. 166, 2018

10. Crandall, R. W., The Failure of Structural Remedies in Sherman Act Monopolization Cases, AEI-Brookings Joint Center for Regulatory Attitudes, Working Paper 01.05., 2001

11. De Locker, J.; Eeckhour, G. U., The Rise of Market Power and Macroeconomic Implications, Quarterly Journal of Economics, Vol. 135(2), 2020, pp. 561 - 644

12. European Parliament, Digital Services Act: EU Legislation in Progress, EPRS study, March 2021

13. European Parliament, Online Platforms: Economic and Societal Effects, EPRS study, March 2021

14. Evans, D. et al., Platform Economics: Essays on Multi-Sided Businesses, Competition Policy International, 2011

15. Hovenkamp, H., Antitrust and Platform Monopoly, ILE Institute for Law and Economics, Research Paper No. 20 - 43, 2020.

16. Rochet, J.; Tirole, J., Platform Competition in Two-Sided Markets, Journal of the European Economic Association, 4/2003, pp. 990-1029.

17. Kades, M.; Morton F. C., Interoperability as a Competition Remedy for Digital Networks, Washington Center for Equitable Growth, Working Paper, 2020

18. Kevin, A. B.; Erik, H., Startup Acquisitions, Error Costs, and Antitrust Policy, The University of Chicago Law Review, Vol. 87, p. 331 - 356

19. Khan, L., The Amazon Antitrust Paradox, Yale Law Journal, Vol. 126(3), 2017, pp. 710 - 805 
20. Kovacic, W. E., Failed Expectations: The Troubled Past and Uncertain Future of the Sherman Act as a Tool for Deconcentration, Iowa Law Review, Vol. 74(4), 1989, pp. 1105 - 1150

21. Odorović, A., Odredivanje relevantnog tržišta kod dvostranih platformi: problemi i nagoveštaji rěsenja, Pravo i privreda, 7-9/2019, pp. 270 - 287

22. Philippon, T., The Great Reversal: How America Gave Up on Free Markets, Belknap Press of Harvard University Press, Cambridge, Mass, 2019

23. Polsky, G. D.; John F. C., Acqui-hiring, Duke Law Journal, Vol. 63(2), 2013, pp. 281 - 346

24. Radulović B., Reassessing the Costs of Patents, in: Vasić R.; Ivana K. (eds.), Razvoj pravnog sistema Srbije i harmonizacija sa pravom EU, University of Belgrade Faculty of Law, 2006, pp. $171-175$

25. Shapiro, C., Antitrust in the Time of Populism, Journal of Industrial Organization, Vol. 62(2), 2018, pp. $714-748$

26. Stigler, J., The Theory of Economic Regulation, Bell Journal of Economics and Management, Vol. 2(1), 1971, pp. $3-21$

27. Sullivan, E. T., The Jurisprudence of Antitrust Divestiture: The Path Less Travelled, University of Minnesota Law School, Vol. 86(2), 2002, pp. 565 - 613

28. Zingales, L., Towards a Political Theory of the Firm, Journal of Economic Perspectives, Vol. 31(3), 2017, pp. $113-130$

\section{WEBSITE REFERENCES}

1. European Commission, The Digital Markets Act: Ensuring Fair and Open Digital Markets, 2021, [https://ec.europa.eu/info/strategy/priorities-2019-2024/europe-fit-digital-age/ digital-markets-act-ensuring-fair-and-open-digital-markets_en], Accessed 02 April 2021

2. FTC Press Releases, FTC Closes Its Investigation Into Facebook's Proposed Acquisition of Instagram Photo Sharing Program, 2012, [https:/www.ftc.gov/news-events/press-releases/2012/08/ftc-closes-its-investigation-facebooks-proposed-acquisition], Accessed 16 March 2021

3. FTC Press Releases, FTC Notifies Facebook, WhatsApp of Privacy Obligations in Light of Proposed Acquisition, 2014, [https://www.ftc.gov/news-events/press-releases/2014/04/ftcnotifies-facebook-whatsapp-privacy-obligations-light-proposed], Accessed 16 March 2021

4. Morton F. C., The European Commission Digital Markets Act: A translation, Vox EU, 5 January 2021, [https://voxeu.org/article/european-commission-digital-markets-act-translation], Accessed 2 April 2021

5. Nobel Laureate Paul Romer on How to Curb Big Tech's Power, 2021, [https://www.chicagobooth.edu/why-booth/stories/stigler-center-antitrust-conference-paul-romer], Accessed 4 April 2021

6. Statista, [https://www.statista.com/statistics/260819/number-of-monthly-active-whatsappusers/], Accessed 26 March 2021

7. Stigler Centre for the Study of the Economy and the State, Stigler Committee on Digital Platforms - Final Report, 2019, [https://www.publicknowledge.org/wp content/uploads/2019/09/Stigler-Committee-on-Digital-Platforms-Final Report.pdf], Accessed, 09 April 2019 
8. White House Statements and Releases, President Biden Announces his Intent to Nominate Lina Khan for Commissioner of the Federal Trade Commission, 2021, [https:/www. whitehouse.gov/briefing-room/statements-releases/2021/03/22/president-biden-announces-his-intent-to-nominate-lina-khan-for-commissioner-of-the-federal-trade-commission/], Accessed 4 April 2021 